\title{
ANALISIS PENYEBAB FLUKTUASI HARGA BARANG POKOK DI PASAR KABUPATEN MAGETAN JAWA TIMUR
}

\author{
Oleh: Naning Pujiati \\ naningpujiati1107@gmail.com \\ (Program Studi Ekonomi Syariah, FEBI IAIN Ponorogo)
}

\begin{abstract}
Abstrak-Harga merupakan sejumlah uang yang dibayarkan pembeli pada penjual yang sebelumnya telah melalui kesepakatan. Harga dapat dipengaruhi oleh beberapa faktor. Dalam penelitian ini akan disajikan harga di pasar dari barang pokok. Penelitian ini dilakukan berdasarkan sumber data sekunder dari instansi terkait yaitu Pusat Sistem Informasi Ketersediaan dan Perkembangan Harga Bahan Pokok di Jawa Timur untuk Kabupaten Magetan periode Oktober 2020 dan data sekunder lainnya. Tujuan penelitian ini adalah menyajikan dan menjelaskan faktor-faktor penyebab perubahan harga. Metode yang digunakan adalah metode analisis kualitatif dengan metode pengumpulan data sekunder dari instansi terkait untuk selanjutnya dilakukan analisis dari data tersebut. Menurut hasil penelitian perubahan harga dapat dipengaruhi oleh permintaan dan penawaran. Selain itu, biaya perolehan juga menyebabkan semakin tingginya harga barang dari pasar induk dan cabang. Semakin sulit perolehan barang maka harga semakin mahal. Perubahan harga juga karena adanya proses tawar menawar atau juga kualitas barang yang dijual.
\end{abstract}

Kata Kunci : Barang Pokok, Harga Pasar, Pembeli, Penjual.

Abstract-The price is the amount of money paid by the buyer on a previously agreed sale. The formation of prices can be influenced by several factors such as the amount of demand and supply, the calculation of the cost of obtaining a product or reactions from other competitors and other factors. In this study, the results will be presented in the form of price data in the market for groups of goods, namely staple goods. This research was conducted on the basis of secondary data sources from related agencies and other secondary data. The data used as a reference in this study is data from the Information System Center for the Availability and Price Development of Staple Materials in East Java for Magetan Regency for the period of October 2020. The purpose of this study is to present the price level of basic goods and explain the factors that cause price changes. In this research also goods. The method used in this observation is a quantitative analysis method with secondary data collection methods from related agencies for further analysis of the data.

Keywords: basic goods, buyer, market, price, seller.

\section{PENDAHULUAN}

Harga adalah sesuatu yang tidak dapat dipisahkah dari kehidupan ekonomi. Harga sangat berkaitan erat dengan permintaan dan penawaran. Dari segi harga 
dapat diketahui juga kualitas dari barang. Bagi sebagian masyarakat harga merupakan faktor pertimbangan dalam melakukan pembelian terhadap suatu produk barang. Walaupun juga ada sebagian dari mereka tidak terlalu mementingkan harga, tetapi lebih mementingkan kualitas walaupun harga lebih mahal.

Harga merupakan sejumlah uang yang di tawarkan oleh penjual kepada pembeli untuk mengganti barang/ jasa. Menjelaskan mengenai harga tidak akan lepas dari peran penjual dan pembeli, banyak orang mengira bahwa faktor yang dapat mempengaruhi perubahan harga sebagian besar disebabkan pengaruh dari penjual dan pembeli. Padahal ada banyak faktor lain selain itu, misalnya faktor yang bukan dari pelaku ekonomi yaitu kondisi geografis pasar, cuaca didaerah, atau becana alam.

Karena cuaca tidak dapat diprediksi, misalkan akibat cuaca tidak menentu juga berpengatuh terhadap panenan sehingga dapat meningkatkan harag suatu barang. Sehingga harga dapat berubah tanpa pengaruh penjual dan pembeli, tetapi penjual dan pembeli tetap dapat memprediksikan kapan harga naik. Missal jika akhir tahun biasanya datang musim penghujan maka harga beras akan naik, dan harga sayuran juga naik karena akibat hujan yang lebat banyak merusak hasil panen sayuran dan lain-lain.
Dalam penelitian ini, akan meneliti mengenai beberapa faktor yang mempengaruhi harga dengan pengelompokan beberapa kelompok barang yaitu barang pokok. Akan disajikan harga 5 barang pokok yaitu beras, gula pasir, minyak goreng, daging, dan telur. Faktor utama dalam pembelian barang yang sangat dipertimbangkan pembeli adalah harga.

Dalam hal ini pedagang harus jeli dalam mennetukan harga karena jika ada kesalahan dalam penetapan harga akan sangat berpengaruh terhadap omset penjualannya. Dalam penetapan hatga jualnya, penjual harus memperhatikan harga dari para pesaing disekitarnya, besarnya biaya yang perolehan barang, dan faktor tingkat keuntungan yang diinginkan.

Menurut Muhammad Irfan Maulana Pradipta berdasarkan penelitiannya terhadap warung yang berada di Yogyakarta, Harga sangatlah berpengaruh dan dianggap hal terpenting dalam membeli produk bagi beberapa kalangan, mereka akan lebih condong memilih produk dengan harga yang lebih murah dibanding harga yang mahal, terlebih jika produk yang akan didapat memiliki kualitas yang lebih baik ( Pradipta, 2018: 5).

Menurut penelitian dari Nurika Muliyah,dkk dalam penelitiannya model transaksi pasar sayur di Blitar, penetuan harga yang telah ditentukan oleh penjual, belum tentu pembeli akan setuju dengan harga tersebut 
sehingga terjadilah tawar menawar harga antara penjual dan pembeli. Ketika harga yang ditawar oleh pembeli terlalu rendah atau tidak kembali modal, penawaran harga yang ditawarkan pembeli tidak akan disetujui. Tetapi penawaran harga akan disetujui ketika harga yg ditawarkan tidak terlalu rendah dan dirasa penjual sudah mendapatkan laba meskipun tidak sesuai dengan harga yg telah ditentukan. (Nurika Mauliyah, 2017:4).

Penelitian ini penting dilakukan dan perlu adanya pengembangan karena dapat digunakan untuk mengetahui sejauh mana peran pembeli dan penjual dalam mempengaruhi harga dipasar khususnya di daerah Magetan. Sehingga penting dilakukan untuk memberi tindakan evaluasi untuk pasar-pasar tersebut.

Penelitian ini bertujuan memberi penjelasan lebih dalam menganalisis faktor penyebab perubahan harga. Disajikan data harga dari beberapa pasar di Kota Magetan, Jawa Timur dengan objek harga barang pokok.

\section{METODE PENELITIAN}

Menurut Arikunto (2013:203) metode penelitian adalah cara yang digunakan oleh peneliti dalam mengumpulkan data penelitiannya. (Arikunto dalam Titin Wulandari, dkk.: 2020, 69). Menurut Nanang Martono, Analisis isi (AI) dan analisis data sekunder (ADS) adalah sebuah solusi untuk menjawab ketakutan akan metode kuantitatif. Dengan menggunakan metode analisis isi atau analisis data sekunder mahasiswa akan terbebas dari masalah waktu penelitian yang lama atau biaya penelitian yang relatif mahal. AI dan ADS adalah metode penelitian yang relatif lebih mudah karena tidak menggunakan manusia sebagai objek penelitiannya. Al dan ADS menggunakan objek yang "tidak hidup" dengan memanfaatkan sumber data yang sudah ada dan tinggal mengolah data tersebut. (Martono, 2017: xvi).

Data yang digunakan dalam penelitian adalah data yang bersumber dari Pusat Sistem Informasi Ketersediaan dan Perkembangan Harga Bahan Pokok di Jawa Timur untuk Kabupaten Magetan periode Bulan Juni dan Oktober 2020 untuk target yang diteliti dan dianalisis adalah harga barang pokok di Pasar Sayur Magetan I, dan Pasar Maospati. Barang pokok yang termsuk dalam penelitian ini adalah beras, gula pasir , minyak goreng, daging, dan telur.

Dalam penelitian faktor harga penulis menggunakan metode penelitian kuantitatif yang datanya diperolah dari data sekunder. Dan menganalisis data tersabut dengan menggunakan metode analisis isi atau analisis kualitatif dari hasil pengamatan penulis. 
Teknik yang digunakan dalam penelitian ini ada 3, yaitu teknik pengumpulan data sekunder dari instansi terkait yaitu dari Pusat Sistem Informasi Ketersediaan dan Perkembangan Harga Bahan Pokok di Jawa Timur untuk Kabupaten Magetan periode Bulan Juni dan Oktober 2020. Kedua adalah teknik perbandingan, yaitu harga dari periode ke periode lain dan harga di pasar satu dengan yang lain. Ketiga adalah teknik analisis harga di pasar dan faktor penyebab perubahannya, yang metodenya menggunakan metode analisis isi atau analisis kualitatif.

\section{HASIL DAN PEMBAHASAN}

Data yang disajikan dlaam hasil penelitian ini adalah data dari Pusat Sistem Informasi Ketersediaan dan Perkembangan Harga Bahan Pokok di Jawa Timur untuk Kabupaten Magetan. Dalam penelitian yang bersumber dari 2 pasar yang ada di Magetan dengan 5 data barang pokok yang disajikan yaitu beras, gula pasir, minyak goreng, daging, dan telur. Dalam penyajiannya ada 2 kurun waktu yaitu, periode Juni 2020 dan Oktober 2020. Berikut adalah penyajian harga barang pokok dalam table untuk Pasar Sayur Magetan 1 (Pusat)

Tabel 1. Harga Barang Pokok di Pasar Sayur Magetan I

\begin{tabular}{|l|c|c|}
\hline \multicolumn{1}{|c|}{ Nama Barang } & Harga/Satuan & Harga/Satuan \\
\hline Beras & Per Juni 2020 & Per Okt 2020 \\
-Bengawan & 10.000 & 10.000 \\
-Mentik & 11.000 & 11.000 \\
-IR 64 & 9.000 & 9.000 \\
& & 12.000 \\
Gula Pasir & 12.500 & 13.000 \\
-Minyak Goreng & 13.500 & 11.000 \\
-Bimoli Botol & 12.000 & 110.000 \\
-Curah & 115.000 & 25.000 \\
Daging & 36.000 & 60.000 \\
-Sapi Murni & 65.000 & 21.000 \\
-Ayam Broiler & & 30.000 \\
-Ayam Kampung & 23.000 & Ketersediaan dan \\
Telur & 30.000 & Sistem Informasi \\
-Ayam Ras & & \\
-Ayam Kampung & (Pusat & \\
Sumber: Siskaperpabo.com & \\
\multicolumn{2}{|c|}{ Perkembangan Harga Bahan Pokok di Jawa Timur untuk Kabupaten } \\
Magetan).
\end{tabular}


Berikut adalah penyajian harga barang pokok dalam table untuk

Pasar Kawedanan:

Tabel 2. Harga Barang Pokok di Pasar Kawedanan

\begin{tabular}{|c|c|c|}
\hline Nama Barang & Harga/Satuan & Harga/Satuan \\
\hline & Per Juni 2020 & Per Okt 2020 \\
\hline \multicolumn{3}{|l|}{ Beras } \\
\hline -Bengawan & 10.000 & 10.000 \\
\hline -Mentik & 11.000 & 11.000 \\
\hline -IR 64 & 9.000 & 9.000 \\
\hline Gula Pasir & 13.000 & 12.500 \\
\hline -Minyak Goreng & & \\
\hline -Bimoli Botol & 12.500 & 13.000 \\
\hline -Curah & 11.000 & 11.000 \\
\hline \multicolumn{3}{|l|}{ Daging } \\
\hline -Sapi Murni & 115.000 & 115.000 \\
\hline -Ayam Broiler & 34.000 & 24.000 \\
\hline -Ayam Kampung & 65.000 & 65.000 \\
\hline \multicolumn{3}{|l|}{ Telur } \\
\hline -Ayam Ras & 23.000 & 21.000 \\
\hline -Ayam Kampung & 30.000 & 30.000 \\
\hline
\end{tabular}

Berdasarkan daftar harga diatas dapat dilihat bahwa harga cenderung rendah di Pasar Sayur Magetan I. Alasannya adalah karena di pasar Sayur Magetan I merupakan pasar induk di Kabupaten Magetan. Sehingga pasar ini sebagai pasar pusat yang di Magetan, dengan pasar yang luas maka dapat menampung penjual dan pembeli yang sangat banyak, sehingga dapat menimbulkan harga lebih rendah daripada pasar lainnya yang lingkupnya adalah kecamatan.

Faktor penyebab dari perubahan harga disetiap harga barang dipasar karena jumlah permintaan dan penawaran. Ketika melihat Pasar Sayur Magetan I yang merupakan pasar induk maka disana akan ditemukan sangat banyak sekali permintaan maka disana akan cenderung memiliki harga yang rendah. Disana juga banyak sekali 
penjual, untuk menarik minat pembeli maka penjual akan mematok harga standart dengan harga pasar. Berbeda untuk Pasar Kawedanan yang kapasitas penjual dan pembeli yang relative lebih sedikit. Apalagi banyak beberapa orang yang memilih membeli barang di Pasar Pusat untuk pembelian barang yang sangat banyak (grosir).

Menurut Penelitian dari Naning Pujiati Pada permintaan beras (barang pokok), para konsumen non-petani cenderung mengabaikan faktor harga. Artinya ketika harga tinggi para konsumen tetap melakukan permintaan, dapat juga ada pengurangan tetapi tidak signifikan. Karena pada dasarnya beras adalah kebutuhan pokok dan utama bagi keluarga. Pada permintaan beras (barang pokok), untuk para petani melakukan banyak permintaan saat belum musim panen dan pada saat musim paceklik karena masa panen masih lama, namun ketika musim panen tiba mereka mengurangi bahkan tidak melakukan permintaan beras.(Pujiati, 2020, 125-126).

Biaya perolehan juga dapat mempengaruhi perubahan harga. Semakin besar biaya perolehan suatu barang maka akan semakin menambah harga barang tersebut. Perbandingan dapat dilihat dari kedua pasar diatas. Pasar Kawedanan merupakan pasar yang berada di Kecamatan Kawedanan, lingkupnya masih satu kecamatan, sehingga sebagin besar bahwa penjual dan pembelinya merupakan warga dalam satu kecamatan tersebut. Penjual yang berada di Pasar Kawedanan kebanyakan barang yang ditawarkan hasil dari panen dan produksi dari kecamatan tersebut, sehingga untuk produk tertentu penjual harus membeli dari pasar induk hal ini dapat menambah biaya perolehan karena dibutuhkan biaya transportasi, biaya untuk pengiriman barang, dan biaya angkat barang.

Pasar Sayur Magetan I dan Pasar Kawedanan adalah salah satu pasar persaingan sempurna dimana didalamnya terdapat banyak penjual dan pembeli. Pasar ini juga termasuk dalam pasar tradisional sehingga para penjual dan pembeli sudah sangat terbiasa dengan kegiatan tawar menawar.Jarang sekali pembeli langsung membayar sesuai permintaan harga penjual, hamper seluruh pembeli pasti akan menawar harga jual yang di tawarkan penjual.

Sejalan dengan pendapat Nurikah Muliyah, dkk dalam penelitiannya pada sebuah Model Transaksi Jual Beli Sayuran di Blitar: Penetuan harga yang telah ditentukan oleh penjual, belum tentu pembeli akan setuju dengan harga tersebut sehingga terjadilah tawar menawar harga antara penjual dan pembeli. Ketika harga yang ditawar oleh pembeli terlalu rendah atau tidak kembali modal, penawaran harga yang ditawarkan pembeli tidak akan 
disetujui.( Nurikah Mauliyah, dkk: 2017, 4).

Selain dari proses tawar menawar, pembentukan tinggi rendahnya harga dipengaruhi oleh teknik distribusi atau penyaluran barang-barang hingga sampai kepada konsumen akhir. Semakin penjang jalur distribusinya maka harga akan semakin tinggi karena semakin panjang jalur distribusinya maka akan lebih banyak dibutuhkan biaya penanganan dan transportasi. Penjual akan memasukkan biaya yang dikeluarkan untuk mendapat barang tersebut terhadap harga barang yang ditawarkan.

Pernyataan diatas sejalan dengan pernyataan dari Toti Indrawati dalam penetiannya Analisis Perilaku Pedagang Dalam Pembentukan Harga Barang Kebutuhan Pokok di Kota Pekanbaru, harga ditingkat konsumen juga dipengaruhi oleh pola distribusi suatu barang semakin panjang saluran distribusi akan semakin mahal harga yang dibeli oleh konsumen akhir. (Indrawati, 2013:4).

Perubahan harga atau pun kestabilan harga barang di Pasar Magetan dapat pengaruhi oleh letak geografis kabupaten Magetan. Di Magetan sebagian besar penduduknya bermata pencaharian petani sehingga ini dapat menyebabkan harga stabil pada komoditas beras di Magetan. Hal serupa juga terjadi pada Gula Pasir, di Magetan terdapat pabrik produksi gula pasir yaitu Pabrik Gula Rejosari, yan terletak di Kelurahan Rejosari, Gorang Gareng, Kec. Kawedanan , Kab. Magetan.

Perubahan haga juga dipengaruhi oleh kualitas dari barang yang bersangkutan. Misalkan saja dari data penelitian, dari jenis barang pokok beras, ini dibedakan atas 3 jenis beras yakni Beras Bengawan, mentik, dan IR 64. Begitu juga dengan minyak, minyak kemasan dalam hal ini di ambil adalah minyak kemasan Bimoli, dan minyak curah yang harganya cenderung lebih murah. Tingkat harga akan menunjukkan tingkat kualitas barang. Semakin tinggi harganya maka akan semakin tinggi kualitas barang yang dijual. Sehingga ini memicu para pembeli mempertimbang kualitas karena kepuasan jauh lebih penting.

Dalam perubahan harga pemerintah juga memberikan peran penting. Pemerintah memberi regulasi mengenai penentuan harga eceran tertinggi. Pemerintah juga ikut berparan dalam perwujudan ekonomi sehat. Dimana pemerintah juga terus memantau pergerakan harga guna menghindari inflasi maupun deflasi. Regulasi yang dibuat pemerintah ditujukan untuk melindungi perdagangan yang menyangkut para pihak yang terlibat di dalam ekonomi.

Dalam bukunya Pengantar Ilmu Ekonomi Mikro T. Silarso 
mengemukakan, jika harga suatu barang dianggap terlalu tinggi sehingga tidak dapat dijangkau lagi oleh masyarakat, maka pemerintah dapat menetapkan harga maksimum atau biasa disebut Harga Eceran Tertinggi (HET) atau celling price. Maksud dari HET ialah bahwa suatu barang tidak boelh dijual dengan harga lebih itnggi daripada yang telah ditetapkan oleh pemerintah. Kalau HET ditetapkan sama dengan atau lebih tinggi daripada harga keseimbangan sebagaimana ditentukan oleh supply dan demand di pasaran, maka penetapan harga ini tidak banyak pengaruhnya ( $\mathrm{T}$. Silarso, 2003: 81).

\section{KESIMPULAN}

Perubahan harga dapat dipengaruhi oleh permintaan dan penwaran, hal ini merujuk pada hukum permintaan dan penawaran. Biaya perolehan juga akan menyebabkan semakin tingganya harga suatu barang. Semakin sulit perolehan barang maka akan semakin menaikkan harga barang. Jumlah pembeli dan penjual juga dapat menimbulkan perubahan harga karena ketika banyak sekali penjula di pasar maka penjual akan mematok harga standar yang dapat menyeimbangkan harga dengan pesaing.

Semakin tinggi harga barang yang dijual oleh penjual, maka akan semakin memicu adanya tawarmenawar, sehingga dapat menurunkan harga di pasar. Karena kebanyakkan pembeli enggan untuk memebeli barang harga yang dipatok dengan harga tinggi tanpa harus menawar dulu.

Kualitas juga mencerminkan harga, semakin tinggi kualitias barang, maka akan semakin tinggi harganya. Penelitian mengenai analisis beberapa faktor yang dapat menyebabkan naik dan turunnya harga barang di pasar, dari penelitian dapat dilihat bukan hanya peran pembeli dan penjual yang dapat merubah harga atau menyebabkan harga mengalami fluktuasi tetapi juga faktor kualitas, faktor alam dan kondisi geografis di daerah yang dapat juga memperngaruhi.

Penelitian ini masih belum menyeluruh, artinya masih banyak objek pasar lainnya yang perlu untuk diteliti guna mencari hasil pengamatan objek baru. Saran untuk peneliti selanjutnya adalah untuk melakukan penelitian kelompok barang yang lain, yang setiap waktu harganya sangat fluktuatif, jika di penelitian ini meneliti pasar dengan barang pokok yang yang menjadi objeknya, maka penelitian selanjutnya dapat menggunakan pasar lain atau menggunakan kelompok barang konsumsi lainnya.

Saran bagi penjual untuk terus melakukan penjualan dengan jujur yaitu ikut melaksanakan kegiatan ekonomi yang bersih dan sehat. Sehingga penjual yang sebagai penyedia barang kebutuhan juga ikut 
andil dalam perwujudan sistem jual beli yang sehat.

Untuk pembeli, supaya agar tidak mementingkan konsumsi berlebih, karena dapat menyebabkan sifat boros, sifat ini disebut juga sifat konsumtif yang jika terus menerus dilakukan akan menyebabkan masyarakat kurang produktif. Seharusnya sedapatnya para pembeli memilah kebutuhan yang diperlukan dan tidak terlalu memboroskan uang sehingga pengeluaran menjadi banyak.

Saran bagi pemerintah untuk terus melakukan upaya untuk menindak tegas para penjual yang curang, yaitu para penjual yang sengaja melakukan penimbunan barang agar harga menjadi naik dan keuntungan juga meningkat.

\section{DAFTAR PUSTAKA}

Indrawati, Toti. (2013). Analisis Perilaku Pedagang Dalam Pembentukkan Harga Barang Kebutuhan Pokok Di Kota Pekanbaru. Jurnal Ekonomi, Volume 21 No. 1 (2020), hal: 4-9.

http://dx.doi.org/10.31258/je.2 1.01.p.\%25p

Martono, Nanang . Metode Penelitian Kuantitatif: Analisis Isi Dan Analisis Data Sekunder 2017: xvi). .PT RajaGrafindo Persada .

Mauliyah, Nurika dkk. (2017). Model Transaksi "Kenceng Jreng" Dan Model "Saur Gowo" Pada Jual Beli Sayuran Di Kabupaten Blitar. Jurnal Ecoment Global, Volume 2
No. 2(2017), hal: 4-8. http://dx.doi.org/10.35908/jeg. $\mathrm{v} 2 \mathrm{i} 2.247$

Pradipta, Muhammad Irfan Maulana. (2018). Mekanisme Penetuan Harga Produk Waroeng Spesial Sambal (SS) Yogyakarta dalam Perspektif Ekonomi Islam (Skripsi). From https://dspace.uii.ac.id/handle/ $123456789 / 9784$

Pujiati, Naning, (2020). Pengaruh Fluktuasi Harga Terhadap Permintaan dan Penawaran Brang Pokok dan Non Pokok. Jurnal Ekonomi dan Pendidikan. Volume 17 No.2(2020), hal: 125-126. https://doi.org/10.21831/jep.v1 $7 \mathrm{i} 2$

Silarso, T. (2003). Pengantar Ilmu Ekonomi Mikro. Yogyakarta: Kanisius.

Wulandari, Titin dkk, (2020). Pengaruh Model Pembelajaran Diskusi Kelas Tipe Beach Ball Terhadap Hasil Belajar Pada Mata Pelajaran Ekonomi. Jurnal Neraca, Volume 4 No.1(2020), hal: 69. http://dx.doi.org/10.31851/nera ca.v4i1.4307 